\title{
Ethanolic Extract of Hedyotis corymbosa L. Inhibits Migration and MMP-9 Activity on Metastatic Breast Cancer Cells
}

\author{
Dhania Novitasari ${ }^{1}$, Sri Handayani ${ }^{2}$, Riris Istighfari Jenie ${ }^{1,3^{*}}$ \\ ${ }^{1}$ Cancer Chemoprevention Research Center (CCRC), Faculty of Pharmacy, Universitas Gadjah Mada, Indonesia \\ ${ }^{2}$ Research Center for Chemistry, Indonesian Institute of Sciences (LIPI), Indonesia \\ ${ }^{3}$ Department of Pharmaceutical Chemistry, Faculty of Pharmacy, Universitas Gadjah Mada, Indonesia
}

\begin{abstract}
Many natural products have been widely explored for their pharmacological activities, including anticancer activity. Hedyotis corymbosa L. is known for its anticancer properties toward several cancer cell lines. The study aims to investigate whether ethanolic extract of Hedyotis corymbosa L. (EEH) performs anticancer properties by inhibiting migration and metastasis on breast cancer cells. Cytotoxic evaluation by using MTT assay was carried out to determine EEH effect on 4TI breast cancer cells, meanwhile to investigate the treatment of EEH in migration and metastasis inhibitory effect, scratch wound healing assay and gelatin zymography were conducted in this study. The data showed that $\mathrm{EEH}$ possessed cytotoxic activity with $\mathrm{IC}_{50}$ value of $400 \mu \mathrm{g} / \mathrm{mL}$. Interestingly, migration inhibitory effect was shown up to 42 hours and the activity of MMP-9 was also decreased after the treatment with EEH. According to these findings, we suggest that Hedyotis corymbosa L. promotes another anticancer properties by inhibiting migration and metastasis towards breast cancer cells.
\end{abstract}

Keywords : Hedyotis corymbosa L., cytotoxicity, migration, metastatic, 4TI breast cancer cells

\section{INTRODUCTION}

The phenomenon of traditional medicine becomes an interesting insight and needs to be explored further in order to find prospective cure for disease, including cancer. The concern about comprehensive research in traditional medicine in Indonesia is not without a reason, because as one of mega biodiversity country by high number of medicinal plants, also the fact that traditional medicine has been commonly used in society to treat disease based on empirical as jamu (Elfahmi, et al., 2014). Hence, the findings of natural resource has been extensively explored to select the ideal candidate which establish the safety and efficacy as anticancer. Moreover, several herbal were developed and commercially used as co-chemotherapy in recent years back, thus the research becomes more aggressively and prospective to find a cure for cancer therapy through several mechanisms (Nurcahyanti, 2016).
Hedyotis corymbosa L. or Rumput Mutiara is one of natural resources which revealed to perform several anticancer properties (Sivapraksam, et al., 2014). Based on phytochemical studies on Hedyotis corymbosa L., several flavonoids, terpenoids, and glycosides were present, such as ursolic acid, oleanolic acid, and gamma sitosterol (Noiarsa, et al., 2008). extract, Previous study reported that Hedyotis corymbosa L. ethanolic extract showed significant anticancer activity on K562 human leukemia cell lines (Pandey, et al., 2012) and on WiDr colon cancer (Meiftasari, et al., 2016). Moreover, its ethanolic extract also revealed its cytotoxic effect on MCF-7 and T47D breast cancer cells with $\mathrm{IC}_{50}$ value of $77 \mu \mathrm{g} / \mathrm{mL}$ and $62 \mu \mathrm{g} / \mathrm{mL}$, respectively (Haryanti, et al., 2009; Andriyani, et al., 2011). However, no

\footnotetext{
Submitted: Feb 19, 2018

Revised: Feb 19, 2018

Accepted: Feb 25, 2018
}

*Corresponding author e-mail : ririsjenie@gmail.com 
study has been done to evaluate the cytotoxic effect of the extract towards metastatic cancer cells.

Breast cancer is known for the most commonly diagnosed cancer and one of the major cause of cancer-related death among females, globally (Torre, et al., 2015). Generally, breast cancer is categorized into estrogen receptor (ER)positive (such as MCF-7 and T47D cell lines) and ER-negative (such as MDA-MB-231 and 4T1 cell lines) breast cancer (Reis-Filho \& Pusztai, 2011). In this study, we focused on triple-negative breast cancer (TNBC), represented by cancer cells that do not express estrogen receptor (ER), progesterone receptor (PR), or HER-2, It becomes the concern and challenge because this type of cancer does not respond to endocrine therapy or other targeted therapy. Furthermore, the metastatic potential in TNBC is similar to the other breast cancer subtypes, but these tumors are associated with potency of relapse and death, thus this distinct subtype of breast cancer would response differently to treatment, which made breast cancer intractable (Hudis and Gianni, 2011). Therefore, based on the explanation before, this study aims to evaluate the potency of ethanolic extract of Hedyotis corymbosa L. (EEH) towards metastatic breast cancer cells.

\section{METHODS}

\section{Extraction of Hedyotis corymbosa L.}

Hedyotis corymbosa L. simplisia was collected and dried before macerated by ethanol $96 \%$ for 5 days. Then, the macerated was filtered before evaporated by using rotary evaporator to obtain the viscous ethanolic extract of Hedyotis corymbosa $\mathrm{L}$.

\section{Cell Culture}

4T1 breast cancer cells were obtained from Prof. Masashi Kawaichi (NAIST, Japan). Cells were grown in Dulbecco's Modified Eagles Medium (DMEM) high glucose (Sigma), supplemented with $10 \%$ FBS (Sigma), HEPES (Sigma), sodium bicarbonate (Sigma), 1,5\% penicillin-streptomycin (Gibco) and 0,5\% fungizone (Gibco) and incubated in $37^{\circ} \mathrm{C}$ with $5 \% \mathrm{CO}_{2}$.

\section{MTT Cytotoxic Assay}

The method using in this study was established by Mosmann (1983) with slight modification. As many as $4 \times 10^{3}$ cells/well of $4 \mathrm{~T} 1$ cells were cultured in 96 -well plate $(100 \mu \mathrm{L} /$ well). After $24 \mathrm{~h}$ incubation, the medium was replaced with series of concentration of EEH. After incubation for $24 \mathrm{~h}$, the medium was discarded and replaced with $0.5 \mathrm{mg} / \mathrm{mL}$ of 3-(4,5-Dimethylthiazol-2-yl)-2,5diphenyltetrazolium bromide (MTT) (Biovision) and incubated approximately $4 \mathrm{~h}$ at $37^{\circ} \mathrm{C}, 5 \% \mathrm{CO}_{2}$. The reaction was stopped with $10 \%$ SDS in $0.01 \mathrm{~N} \mathrm{HCl}$ solution and was incubated in dark condition for overnight to dissolve formazan salt. Cells absorbance was measured with ELISA reader at 595 nm. Cells absorbance was converted to \% cell viability. Linear regression between concentration and $\%$ cell viability giving the equation $\mathrm{y}=\mathrm{Bx}+\mathrm{A}$ were used to calculate $\mathrm{IC}_{50}$ value, that is the concentration inhibiting $50 \%$ cell proliferation.

\section{Wound Healing Assay}

The $4 \mathrm{~T} 1$ cells (briefly $7.5 \times 10^{4}$ cells/well with $500 \mu \mathrm{L}$ of complete medium) were seeded in 24 well-plate and incubated for $24 \mathrm{~h}$. The starvation of cells was done by replacing the medium with culture medium supplemented with $0,5 \%$ FBS for $24 \mathrm{~h}$. After starvation, the cells were scratched with sterile yellow tip in a straight line and treated with $2 \mathrm{~mL}$ of series of concentration sample $\left(1 / 8 ; 1 / 4 ; 1 / 2 \mathrm{IC}_{50}\right.$ of EEH). The cells were documented at $0,18,24$, and $42 \mathrm{~h}$ after treatment by digital camera (Nikon, Japan). The results were analyzed by ImageJ software and presented as \% of wound closure then statistically analyzed by using SPSS 17.0.

\section{Gelatin Zymography}

The $4 \mathrm{~T} 1$ cells $\left(3 \times 10^{5}\right.$ cells) were seeded on 6 well plate and treated by EEH at concentration of 50, 100 and $200 \mu \mathrm{g} / \mathrm{mL}$ for $24 \mathrm{~h}$. Each medium was collected as lysate protein then the total protein of lysate was normalized by Bradford method and was used as samples for gelatin zymography. The $10 \%$ of SDS-PAGE supplemented with $0.1 \%$ of gelatin was used to determine the activity of MMP-9 in the culture medium. After electrophoresis, gels were washed and incubated with distilled water containing $2 \%$ of Triton-X 100 (Merck) for $30 \mathrm{~min}$ at room temperature. The solution was removed from gels, then $100 \mathrm{~mL}$ of reaction buffer $(40 \mathrm{mM}$ Tris- $\mathrm{HCl} \mathrm{pH}$ 8, $10 \mathrm{mM} \mathrm{CaCl}_{2}, 0.02 \% \mathrm{NaN}_{3}$ ) was added and incubated for $24 \mathrm{~h}$ at $37^{\circ} \mathrm{C}$. After removal of reaction buffer, gels were stained by Coomassie Brilliant 
Blue R-250 solution and destained by destaining solution (20\% methanol, $10 \%$ acetic acid and $70 \%$ water) until clear bands with dark blue background appear. The results were documented and analyzed by ImageJ software (Hsieh, et al., 2013)

\section{Statistical analysis}

Data were expressed as mean \pm SE. One-way analysis of variance (ANOVA) followed by the least significant difference (LSD) test were used for statistical analyses. P-values less than 0.05 were considered significant.

\section{RESULTS}

\section{Cytotoxic Effect of Ethanolic Extract of} Hedyotis corymbosa L. on 4TI Breast Cancer Cells

Cytotoxic assay was carried out to determine the potential role of Hedyotis corymbosa L. and underlying mechanism on metastatic breast cancer cells, particularly when administered in single treatment and was presented by $\mathrm{IC}_{50}$ value. The single treatment of $48 \mathrm{~h}$ of treatment inhibited cell growth in a dose dependent manner with the $\mathrm{IC}_{50}$ value of $400 \mu \mathrm{g} / \mathrm{mL}$ (Fig. 1).

\section{Ethanolic Extract of Hedyotis corymbosa L. Inhibited 4T I Cells Migration}

For this assay, we used $1 / 8,1 / 4$, and $1 / 2 \mathrm{IC}_{50}$ value of HEE acquired from MTT assay to evaluate inhibitory effect of EEH on cells migration. Based on the result of scratch wound healing assay up to 42 hours showed that single treatment with ethanolic extract of Hedyotis corymbosa L. showed inhibitory effect on 4T1 cells migration (Fig. 2). Furthermore, EEH was found to inhibit cells migration up to $30 \%$ compared to control after 42 hours of incubation.

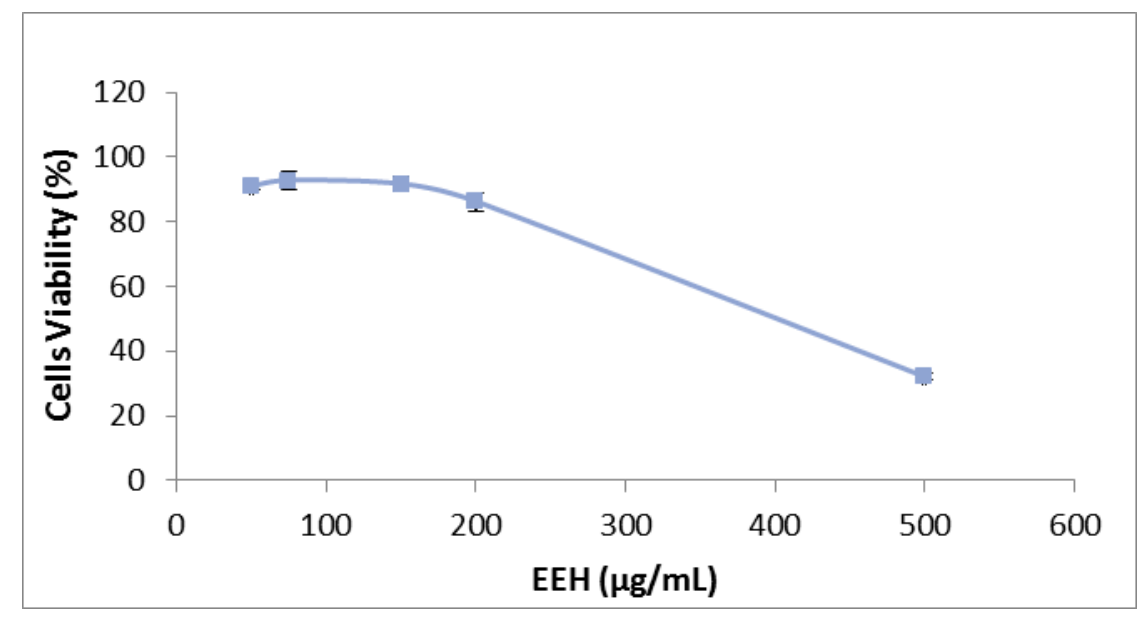

Figure I. Cytotoxic Effect of EEH on 4TI cells. As many as 4x103 cells/well 4TI cells were seeded in 96 well-plate and incubated for $24 \mathrm{~h}$, then treated with EEH for 48 hours. Cells viability was determined by using MTT assay as described in methods. The cells viability profile after treatment of EEH on 4TI cells. Profiles of cell viability were described as means \pm SE from 3 independent experiments. 


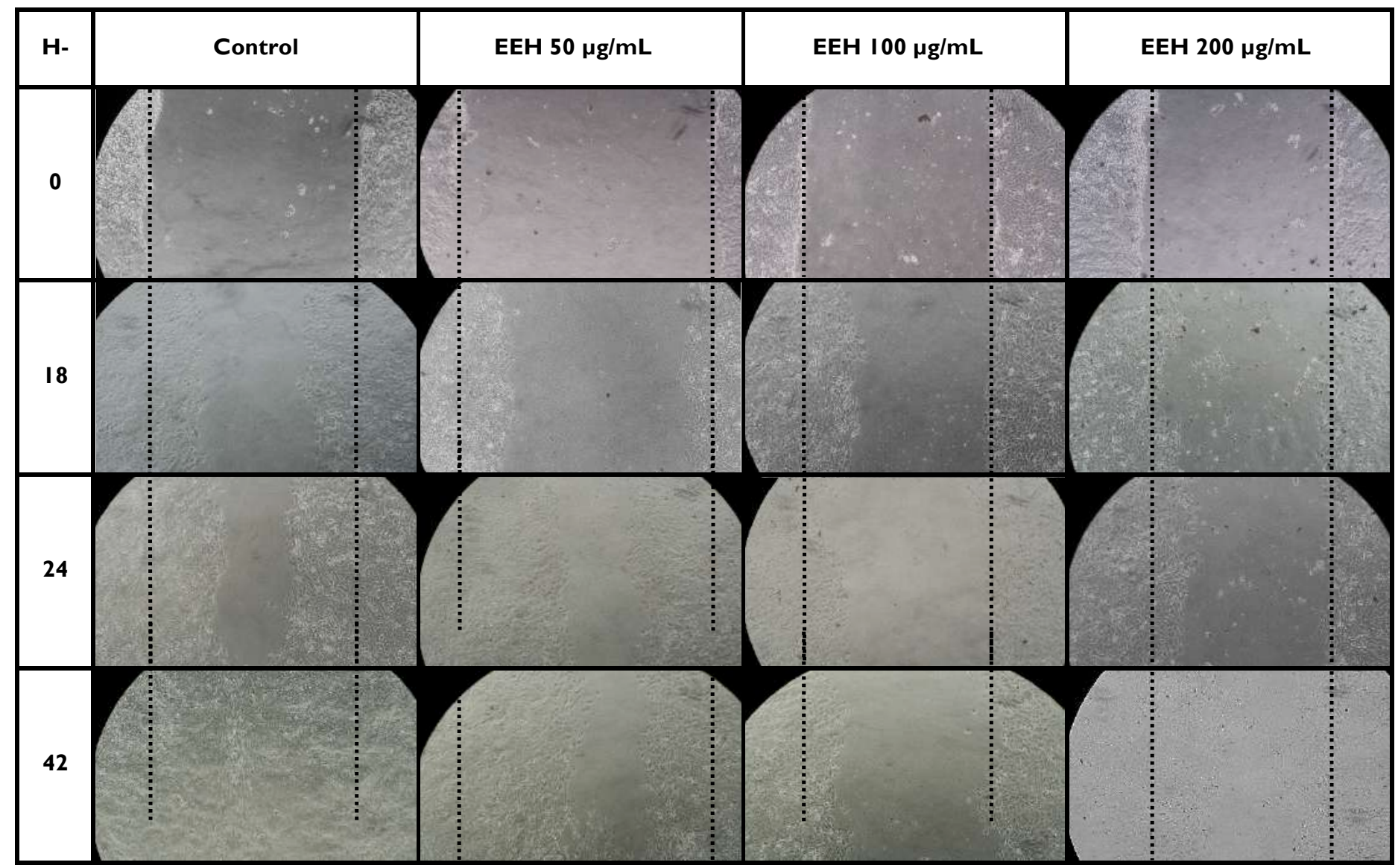

(A)

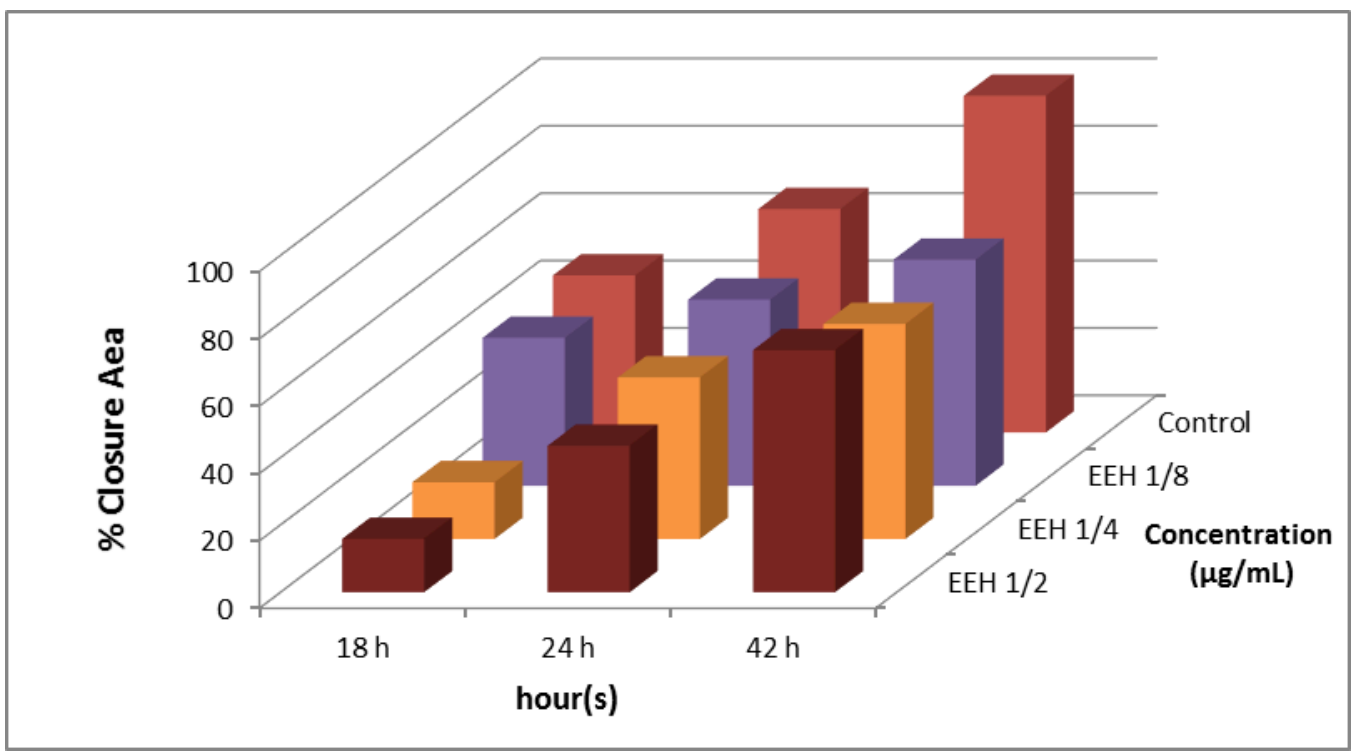

(B)

Figure 2. Effect of Treatment with Ethanolic Extract of Hedyotis corymbosa L. on 4T I Cells Migration. (A) The morphology of the cells after scratch and treated with EEH. Observations were made after 0, 18, 24 and 42 hour of treatment under an inverted microscope with magnification of 100x. Black dashed dot line indicated scratching area at the time of observation. (B) The percentage of $4 \mathrm{TI}$ cells closure after 18, 24, and $42 \mathrm{~h}$ of treatment. Values were described as means of \%. The area of the scratch were analyzed using Image software then \% closure was calculated in accordance with the procedures of the analysis. 
Ethanolic Extract of Hedyotis corymbosa L. Reduced MMP-9 Activity on 4TI Metastatic Breast Cancer Cells

In order to evaluate whether EEH modulate in MMP-9 activity which play an important role in cells signaling to migrate on $4 \mathrm{~T} 1$ metastatic breast cancer cells, we carried out assay using gelatin zymography. Results showed that single treatment up to $200 \mu \mathrm{g} / \mathrm{mL}$ of EEH relatively tend to decrease the gelatinase activity level of MMP-9 (Fig. 3). We suggested that EEH inhibited cells invasion possibly through inhibition of MMP-9 activity.

\section{DISCUSSION}

The treatment using ethanolic extract of Hedyotis corymbosa L. showed inhibition of cells growth on $4 \mathrm{~T} 1$ metastatic breast cancer cells with $\mathrm{IC}_{50}$ value of $400 \mu \mathrm{g} / \mathrm{mL}$ after 48 hours of treatment. This phenomenon occurs due to its major compound, ursolic acid, has been known to exhibit cytotoxic effect after 48 hours of treatment (Harmand, et al., 2005; Li, et al., 2010). Several previous reports also have been revealed that Hedyotis corymbosa L. exhibited cytotoxic effect on cancer cell lines, including K562 cells, WiDr cells, COLO 205 cells, Hep3B cells, H460 cells, also on T47D and MCF-7 breast cancer cells (Pandey, et al., 2012; Meiftasari, et al., 2016; Lee, et al., 2011; Andriyani, et al., 2011; Haryanti, et al., 2009). According to study by Endrini (2011), the cytotoxic effect from Hedyotis corymbosa L. was associated with high antioxidant activities from flavonoid and phenolic compounds in extract. Moreover, ursolic acid which abundantly contained on Hedyotis corymbosa L. was also reported to inhibit cells proliferation and modulate multiple signaling pathways such as suppressing FoxM1 expression, STAT3, Jun N-terminal kinase, and NF-kB (Wang, et al., 2013; Xavier, et al., 2013; Prasad, et al., 2012).

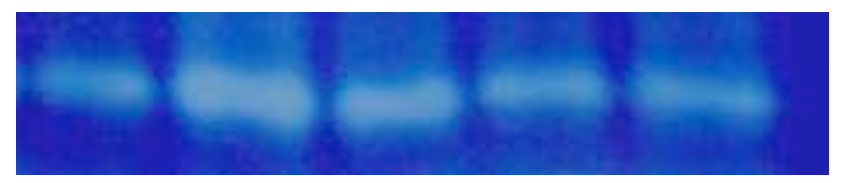

Control $\quad 40 \mu \mathrm{g} / \mathrm{mL} \quad 50 \mu \mathrm{g} / \mathrm{mL} \quad 100 \mu \mathrm{g} / \mathrm{mL} 200 \mu \mathrm{g} / \mathrm{mL}$

(A)

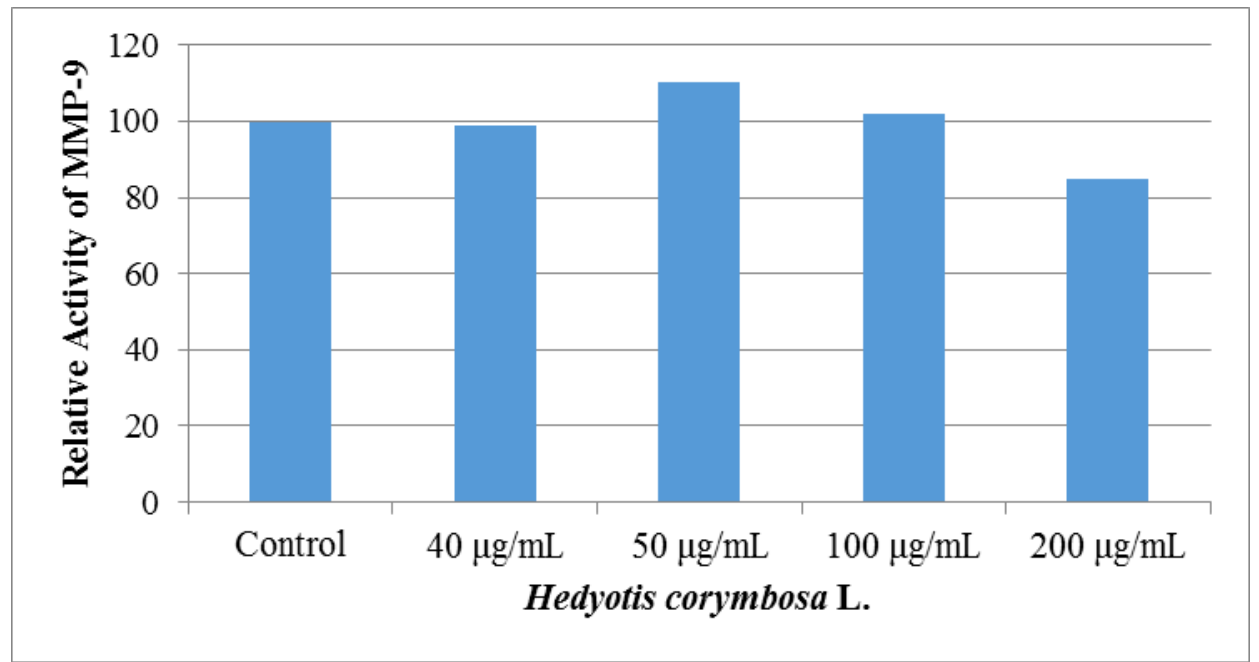

(B)

Figure 3. Effect of Single Treatment of ethanolic extract of Hedyotis corymbosa L. in MMP-9 Activity on 4TI Metastatic Breast Cancer Cells. (A) Transparent bands profile of MMP-9 expression (B) Quantification of transparent band intensity of MMP-9. MMP-9 activity assay was conducted using gelatin zymography as described in the method. Analysis of the results were done by using Image software to measure the intensity of gelatin degradation by MMP-9 in the gel. 
In this present study, inhibition of cancer metastasis after treatment of EEH was also observed. Cell migration is part of the process of metastasis. Based on the result, the treatment of EEH revealed to inhibit $4 \mathrm{~T} 1$ cells migration up to 42 hours after treatment. Moreover, single treatment of EEH also tend to inhibit cancer cell invasion process by reducing the activityt of matrix metalloproteinase- 9 (MMP-9). The possible molecular mechanism which cause this finding is inhibition of NF- $\mathrm{KB}$ activation as one of MMP-9 transcription factor. Previous research stated that ursolic acid compound suppresed the MMP-9 and VEGF activities (Prasad, et al., 2016). Thus, there is high possibility that EEH suppressed NF- $\mathrm{KB}$ activation and MMP-9 activity which play a responsible role in invasion and metastasis of cancer cells and needed to be investigated further.

\section{CONCLUSION}

Taken together, Ethanolic extract of Hedyotis corymbosa L. reveals to inhibit cancer cells growth, also inhibits cell migration and MMP-9 activity on 4T1 metastatic breast cancer cells. These results added the potency from Hedyotis corymbosa $\mathrm{L}$. to be developed as anticancer agent based on medicinal plants.

\section{REFERENCES}

Andriyani, R., Risdian, C. and Udin, Z., 20II, Cytotoxicity Assay From Fractions of Hedyotis corymbosa Extract Against Breast Cancer Cell Line T47D, Indones. J. Cancer Chemoprevent., 2(I), I82-186.

Elfahmi, Woerdenbag, H. J. and Kayser, O., 2014, Jamu: Indonesian traditional herbal medicine towards rational phytopharmacological use, J. Herbal Med., 4(20I4), 5I-73.

Harmand, P. O., Duval, R., Delage, C. and Simon, A., 2005, Ursolic acid induces apoptosis through mitochondrial intrinsic pathway and caspase-3 activation in M4Beu melanoma cells, Int. J. Cancer, I I 4(I), I-II.

Haryanti, S., Junedi, S. and Meiyanto, E., 2009, Ethanolic Extract of Hedyotis corymbosa L. Increases Cytotoxic Activity of Doxorubicin on MCF-7 Breast Cancer Cell, Indones. J. Biotechnol., I 4( I), I |46-I I 54.
Hsieh, C.Y., Tsai, P.C., Chu, C.L., Chang, F.R., Chang, L.S., Wu, Y.C., et al., 2013, Brazilein Suppresses Migration and Invasion of MDAMB-23I Breast Cancer Cells, Chemicobiological interactions, 204(2), I05-II 5.

Hudis, C.A. and Gianni, L., 20II, Triple-negative Breast Cancer: An Unmet Medical Need, Oncologist., I 6(SuppI I), I-I I.

Lee, H.Z., Bau, D.T., Kuo, C.L., Tsai, R.Y., Chen, Y.C. and Chang, Y.H., 20II, Clarification of the phenotypic characteristics and anti-tumor activity of Hedyotis diffusa, Am. J. Chin. Med., 39(0I), 20l-2I3.

Li, Y., Xing, D., Chen, Q. and Chen, W. R., 2010, Enhancement of Chemotherapeutic Agent induced Apoptosis by Inhibition of NF-kB Using Ursolic Acid, Int. J. Cancer, I 27(2), 462473.

Meiftasari, A., WP, J.C., Novarina, A., Yovi, J. and Jenie, R.I., 2016, Ethanolic Extract of Hedyotis corymbosa and Its Combination with 5-FU Inhibit Cyclin D Expression on WiDr Colorectal Cancer Cell, Indones. J. Cancer Chemoprevent., 7(I), 25-30.

Mosmann, T., 1983, Rapid colorimetric assay for cellular growth and survival: application to proliferation and cytotoxic assays, J. Immunol. Methods, 65(I-2), 55-63.

Noiarsa, P., Ruchiwarat, S., Otsuka, H. and Kanchanapoom, T., 2008, Chemical Constituents from Oldenlandia corymbosa L. of Thai origin, J. Nat. Med., 62(2), 249250.

Nurcahyanti, A.D.R., 2016, Cervical Cancer: The Case in Indonesia and Natural Product-Based Therapy, J. Cancer Biol. Res., 4(I), 1078.

Pandey, K., Sharma, P.K. and Dudhe, R., 2012, Anticancer Activity of Parthenium Hysterophorus Linn and oldenlandia corymbosa Lam by SRB Method, Sci. Rep., I(6), I-3.

Prasad, S., Yadav, V.R., Sung, B., Reuter, S., Kannappan, R., Deorukhkar, A., et al., 2012, Ursolic acid inhibits growth and metastasis of human colorectal cancer in an orthotopic nude mouse model by targeting multiple cell signaling pathways: chemosensitization with capecitabine, Clin. Cancer Res., I 8(18), 49424953. 
Prasad, S., Yadav, V.R., Sung, B., Gupta, S.C., Tyagi, A.K. and Aggarwal, B.B., 2016, Ursolic Acid Inhibits the Growth of Human Pancreatic Cancer and Enhances the Antitumor Potential of Gemcitabine in An Orthotopic Mouse Model Through Suppression of the Inflammatory Microenvironment, Oncotarget, 7(II), 13182 .

Reis-Filho, J.S. and Pusztai, L., 201I, Gene Expression Profiling in Breast Cancer: Classification, Prognostication, and Prediction, Lancet, 378(9805), I8|2-1823.

Sivapraksam, S.S.K., Karunakaran, K., Subburaya, U. and Kuppusamy, S., 2014, A Review on Phytochemical and Pharmacological Profile of Hedyotis corymbosa Linn., Int. J. Pharm. Sci. Rev. Res., 26(I), 320-324.
Torre, L.A., Bray, F., Siegel, R.L., Ferlay, J., Lortet-Tieulent, J. and Jemal, A., 2015, Global Cancer Statistics, 2012, CA Cancer J. Clin., 65(2), 87-108.

Wang, W., Zhao, C., Jou, D., Lu, J., Zhang, C., Lin, L., et al., 2013, Ursolic Acid Inhibits the Growth of Colon Cancer-initiating Cells by Targeting STAT3, Anticancer Res., 33(10), 4279-4284.

Xavier, C. P., Lima, C.F., Pedro, D.F., Wilson, J.M., Kristiansen, K. and Pereira-Wilson, C., 2013, Ursolic Acid Induces Cell Death and Modulates Autophagy through JNK Pathway in Apoptosis-resistant Colorectal Cancer Cells, J. Nutr. Biochem., 24(4), 706-7I2. 